\title{
BMJ Open Comparative study analysing women's childbirth satisfaction and obstetric outcomes across two different models of maternity care
}

\author{
$\mathrm{M}^{\mathrm{a}}$ Belén Conesa Ferrer, ${ }^{1}$ Manuel Canteras Jordana, ${ }^{2}$ \\ Carmen Ballesteros Meseguer, ${ }^{3}$ César Carrillo García, ${ }^{4} M^{a}$ Emilia Martínez Roche ${ }^{4}$
}

To cite: Conesa Ferrer $M^{a} B$ Canteras Jordana M, Ballesteros Meseguer C, et al. Comparative study analysing women's childbirth satisfaction and obstetric outcomes across two different models of maternity care. BMJ Open 2016;6: e011362. doi:10.1136/ bmjopen-2016-011362

- Prepublication history for this paper is available online. To view these files please visit the journal online (http://dx.doi.org/10.1136/ bmjopen-2016-011362).

Received 5 February 2016 Revised 30 May 2016 Accepted 1 June 2016

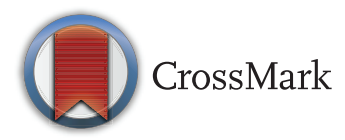

${ }^{1}$ Department of Nursing at the University of Murcia, Midwife in the University Hospital of Torrevieja, Murcia, Spain

${ }^{2}$ Department of Statistics, Murcia University, Murcia, Spain

${ }^{3}$ Department of Nursing at the University of Murcia, Midwife in the University Hospital Virgen de la Arrixaca, Murcia, Spain ${ }^{4}$ Department of Nursing, Murcia University, Murcia, Spain

Correspondence to Dr Mª Belén Conesa Ferrer; mb.conesaferrer@um.es

\section{ABSTRACT}

Objectives: To describe the differences in obstetrical results and women's childbirth satisfaction across 2 different models of maternity care (biomedical model and humanised birth).

Setting: 2 university hospitals in south-eastern Spain from April to October 2013.

Design: A correlational descriptive study.

Participants: A convenience sample of 406 women participated in the study, 204 of the biomedical model and 202 of the humanised model.

Results: The differences in obstetrical results were (biomedical model/humanised model): onset of labour (spontaneous 66/137, augmentation 70/1, $\mathrm{p}=0.0005$ ), pain relief (epidural 172/132, no pain relief $9 / 40$, $p=0.0005$ ), mode of delivery (normal vaginal $140 / 165$, instrumental $48 / 23, p=0.004$ ), length of labour (0-4 hours 69/93, $>4$ hours 133/108, $p=0.011$ ), condition of perineum (intact perineum or tear $94 / 178$, episiotomy $100 / 24, p=0.0005$ ). The total questionnaire score (100) gave a mean (M) of 78.33 and SD of 8.46 in the biomedical model of care and an $\mathrm{M}$ of 82.01 and $\mathrm{SD}$ of 7.97 in the humanised model of care

$(p=0.0005)$. In the analysis of the results per items, statistical differences were found in 8 of the 9 subscales. The highest scores were reached in the humanised model of maternity care.

Conclusions: The humanised model of maternity care offers better obstetrical outcomes and women's satisfaction scores during the labour, birth and immediate postnatal period than does the biomedical model.

\section{BACKGROUND}

Satisfaction with childbirth is considered the most important qualitative outcome in assessing childbirth experience, ${ }^{1}$ given that women's satisfaction with this experience affects their health and their relationship with their infant. $^{2}{ }^{3}$ Thus, it is crucial to study women's satisfaction with childbirth as an indicator of the quality of maternity care. ${ }^{4}$

\section{Strengths and limitations of this study}

- This is the first study comparing women's satisfaction across two different models of maternity care.

- It is a quantitative and multicentre study with a sample large enough to achieve our objectives.

- The convenience sample and the timing chosen for completing the questionnaires were limitations in our study.

- It would be necessary to extend the study to other areas and to include more hospitals in order to extrapolate the results.

In this sense, Séguin et at identified five dimensions: the delivery experience (pain intensity, complications and length of labour), medical care, nursing care, information received and participation in the decision-making process, and physical aspects of the labour and delivery rooms. Drew et $a t^{6}$ identified the following features of obstetric care as influencing satisfaction with childbirth: explanation of procedures and involvement of mothers in administering or choosing them; support from the presence of a partner and qualified hospital staff; and physical comfort of the postnatal ward. Lavender $e t a l^{7}$ described factors contributing to a satisfying birth experience as follows: support, information, intervention, decisionmaking, control, pain relief and trial participation. Hodnett, ${ }^{4}$ systematically reviewing 137 reports of factors influencing women's evaluations of their childbirth experiences, noted that the following factors influenced satisfaction: personal expectations, the amount of support from caregivers, the quality of the caregiver-patient relationship and involvement in decision-making. These interpersonal factors proved more important than demographic factors such as age, 
socioeconomic status, ethnicity, childbirth preparation, physical environment, pain, immobility, medical interventions and continuity of care. ${ }^{4}$

The present research focuses on two different models of maternity care. In the 20th century, the technological development in the obstetric field changed childbirth to a biomedical model. Delivery at home was slowly replaced by hospital deliveries, and giving birth became a medicalised procedure in most countries. ${ }^{8}$ Births were conceptualised as a pathological process requiring intensive monitoring and the use of medical interventions such as electronic fetal monitoring (EFM), epidural analgesia, amniotomy, induced labour, episiotomy and elective caesarean section deliveries. In the biomedical model of birth, the doctor always took control. ${ }^{9}$ Medical staff treated all births with the same high level of intervention necessary only for those who undergo complications. Medical care reinforces the perception of the mother's role as a patient, causing the woman to lose control and autonomy of her delivery. The uncritical adoption of inappropriate interventions, frequently poorly evaluated, is a risk run by many who try to improve maternity services. For this reason, the WHO had to clarify, in the light of current knowledge and evidence-based medicine, which practices were appropriate in normal birth care. ${ }^{10}$ Other authors have published guides to effective care in childbirth based on the evidence-based care. $^{11} 12$

Under the WHO's recommendations, another model of maternity care appeared, the humanised one. In the International Conference on Humanization, held in Brazil (2000), the concept of 'humanisation' was defined, emphasising labour and birth, due to the importance of these two events in women and their families' life, and the humanisation of birth was deemed an urgent and evident necessity. ${ }^{13}$ Humanised birth means placing the woman giving birth in the centre and in control in order to promote the active participation of the mother. ${ }^{9}$ Humanising birth also means considering women's beliefs, values and feelings and respecting their autonomy and dignity during the birthing process. ${ }^{14-16}$ This new paradigm of birth tends to reduce the use of technological interventions in normal births because both the women and the obstetricians consider birth as being primarily physiological rather than potentially pathological. The barriers against humanised birth care include the lack of decision-making by the mother in hospitals; university-affiliated hospitals; malpractice litigation; the lack of midwife authority in hospitals; the shortage of healthcare professionals; the lack of sufficient communication among professionals; the stakeholders' desire for specialisation rather than humanisation; common labour, delivery and postpartum rooms; companion restriction; unnecessary medical interventions; a lack of privacy; and an absence of continuity of care. ${ }^{14} 17$

The coverage of the maternity care system in Spain is universal and equitable. The Spanish National Health System is decentralised and each regional government is in charge of the functioning of this system in their region. In Spain, the main model of maternity care is the biomedical one. ${ }^{18}$ In an attempt to change this situation, a document on birth assistance was published in 2006 by the Spanish Society of Obstetrics and Gynaecology. In this document, selective use of episiotomy and avoiding the use of pubic shaving was recommended. Several regional governments tried to promote normal birth and to guarantee the rights of mothers and their children. Currently, the governments of Andalusia, Catalonia and Cantabria have legislation concerning assistance to normal birth. ${ }^{19-21}$ The Spanish Federation of Midwife Associations drafted a consensus document called 'Normal Birth Initiative', based on scientific evidence. It is used as a guide to teach midwives how to assist a normal birth and provides them the security to do so. ${ }^{22}$

The Spanish National Healthcare System approved the Care Strategy for Normal Childbirth in all regions of the nation. This is giving rise to a far-reaching change in the childbirth care model. This consensus document presents a view of childbirth as a generally physiological process. Therefore, it highlighted the importance of offering personalised, holistic care addressing biological, emotional and family issues, based on scientific evidence while respecting the mother's central role. ${ }^{23}$ In addition to this strategy and within the context of the Quality Plan for the Spanish National Healthcare System of the Ministry for Health and Consumer Affairs, a programme developed evidence-based Clinical Practice Guidelines to assist normal birth. According to this guide, published in 2010, in normal labour there should be a valid reason for any interference in the natural process. These developments have led professionals and women to change their minds with regard to birth assistance.

The aim of the present study was to identify the differences in factors related to childbirth satisfaction and obstetrical results between two contrasting models of delivery, the biomedical model and the humanised model.

\section{METHODS}

A correlational descriptive study was conducted with 406 mothers aged 16-43 years, at two university hospitals in south-eastern Spain, one located in the city of Alicante (hereafter referred to as hospital A) and the other in the city of Murcia (hereafter referred to as hospital B).

\section{SETTINGS}

Both hospitals are state-run and public. Normally, mothers go to the maternity ward nearest their residence and thus are not allowed to choose the hospital, although in an emergency (eg, mother is in the active phase of labour) a pregnant woman may be attended to at any hospital. Hence, mothers cannot choose the model of maternity care. 
Midwives normally do not have autonomy in most hospitals of Spain, because most of them are from the biomedical model. However, hospital A promotes their autonomy. The large differences between the two hospitals are due to the fact that these hospitals have different protocols of birth assistance. Protocols of hospital A are based on the recommendations on normal birth assistance of the WHO and the Spanish National Healthcare System (Care Strategy for Normal Childbirth and Clinical Practice Guidelines to assist normal birth). Hospital A protocols were established by gynaecologists and midwives.

Hospital A tried to implement a humanised model of birth for 1189 births in 2013. This hospital provides all women with humanised maternity care. The physical environment consisted of five individual labour, delivery and postpartum rooms. Women and their husbands/ companions had privacy during the process of birth (labour, birth and the two postpartum hours). They had space for walking and for changing posture during the process of dilation and birth. This hospital provides more normal vaginal deliveries than in the biomedical model. Preventing unnecessary medical intervention such as the use of routine EFM, amniotomy, epidural analgesia, intravenous infusion, episiotomy, induced labour, labour augmentation and elective section delivery constitutes a major strategy used to implement humanised birth. This hospital offers natural methods for pain relief, including breathing techniques, massages, thermo therapy, soaking in a hot bath, warm blankets, listening to music, and emotional and psychological support from the midwives. This hospital uses epidural analgesia and not anaesthesia. Epidural analgesia has fewer side effects, less motor block than the biomedical model since epidural analgesia with a lower-than-usual dose of local anaesthesia is used.

Midwives are the main providers in normal births. Midwives promote the active participation of women regarding decision-making. Skin-to-skin mother/baby contact is offered for 2 hours after birth, and early breast feeding is also promoted.

Hospital B has a biomedical model of maternity care. The number of births in this hospital was 7288 in 2013. The physical environment consists of four double labour rooms, where there is little space and the mother and her companion have no privacy. Mothers remain in one of these birthing units only during labour. There are three delivery rooms where the mother and her companion stay during the birthing process. There is a large common postpartum room where all mothers are located after birth. Mothers are not allowed to be accompanied during the two postpartum hours. Skin-to-skin mother/baby contact is possible only for $10 \mathrm{~min}$, after which the baby is weighed and dressed before being placed in the postpartum room with the mother. Early breast feeding is also promoted. This hospital promotes active management of labour. Births are routinely managed by EFM, amniotomy, epidural analgesia, intravenous infusion, episiotomy, induced labour and augmentation. Epidural analgesia has more side effects, more motor block than found in the other hospital. Doctors and midwives are the providers in normal deliveries. Doctors are always in control and decide what choices the mothers are allowed about their birth. The mothers' lack of full participation in the decision-making process and their generally passive role is considered normal in this setting.

\section{SAMPLE}

A convenience sample of 406 women who participated in this study between April and October 2013. All women were asked to complete the questionnaire in the postnatal ward. The women who were excluded from the study were: women who entered the hospital for elective caesarean and women who could not understand the Spanish or English language, since the questionnaire was written in these two languages. None of the women who were invited to participate in the study declined. The sample size was estimated to provide $80 \%$ power to detect a difference of $15 \%$ between two proportions (power $=80 \%, \alpha=0.05$ ). This resulted in a sample size of 188 . A further $10 \%$ were selected to offset a $10 \%$ loss. Finally, 204 women from the biomedical model and 202 women from the humanised one were recruited for the study. Women were not excluded for having complications during labour.

Informed consent was given by all respondents, who were given a questionnaire during their postpartum hospital stays.

\section{QUESTIONNAIRE}

All participants completed the Women's Views of Birth Labour Satisfaction Questionnaire (WOMBLSQ), which is a quantitative psychometric multidimensional maternal-satisfaction questionnaire. ${ }^{24}$ It consisted of 10 dimensions in addition to general satisfaction. These were: professional support during labour, expectations of labour, home assessment in early labour, holding the baby, support from husband/partner, pain relief in labour, pain relief immediately after labour, knowing labour caregivers, labour environment and control in labour. All 'questions' were statements which required respondents to mark a seven-point scale from 'totally disagree' to 'totally agree'. In this study, this questionnaire was adapted by permission from BMJ Publishing Group Limited (Development of a multidimensional laboursatisfaction questionnaire: dimensions, validity, and internal reliability; LFP Smith, 10, 17-22, 2001). Two dimensions had to be avoided: 'home assessment' and 'continuity', because in Spain there is no caregiver who visits pregnant women at home to check their state. Furthermore, midwives/caregivers are not the same in primary care and hospital attendance and therefore women could not assess these subscales. The response format was a four-point Likert scale instead of a seven- 
point Likert scale, in order to have less dispersed answers. Questionnaires were scored per item. Positive items were valued from 1 to 4 points ( 1 point: 'totally disagree', 4 points: 'totally agree'), as were negative items (1 point: 'totally agree', 4 points: 'totally disagree'). The questionnaire was also translated into Spanish by a professional translator. When half of the sample had been collected, an orthogonal (varimax) rotation was conducted to check whether the modified version of the questionnaire identified all factors involved. The eight factors accounted for $68.48 \%$ of the total variance. The factors identified were: professional support $(26.87 \%)$, expectations $(9.85 \%)$, pain in labour $(6.95 \%)$, holding the baby $(6.16 \%)$, control $(5.25 \%)$, support from the husband $(5.05 \%)$, pain after delivery $(4.32 \%)$ and the environment $(4.03 \%)$. These results were very similar to the original ones of the questionnaire. After collecting the entire sample, the eight factors accounted for $70.22 \%$ of the variance, and Cronbach's $\alpha$ of 0.82 resulted for the total questionnaire.

Data on obstetric analgesia, medical interventions, duration of labour, mode of delivery, condition of the perineum and state of the infant were taken from medical records. Length of labour was measured from the time the mother entered the birth room (this moment is registered in the partogram) until she gave birth.

\section{ANALYSIS}

Statistical analyses were conducted using SPSS V.20.0 for Windows. Student's t-test, with unspooled SD, was used to compare means of the questionnaires' overall results. Contingency tables were tested by the $\chi^{2}$ function. A $\mathrm{p}$ value of $<0.05$ was required for statistical significance. Exploratory factor analysis was performed to examine the construct validity of the modified version of the WOMBLSQ. Orthogonal (varimax) rotation was conducted. Reliability of the modified version of the WOMBLSQ questionnaire was assessed with the Cronbach's $\alpha$ coefficient. Discriminant analysis (DA) was performed to evaluate the variables that contribute most to the discrimination of the two models of maternity care.

\section{ETHICS APPROVAL}

Ethics approval was given by the Research Ethics Committees from the two hospitals where the study was conducted. The mothers participating agreed to complete the questionnaire and also to the use of their hospital records. They were informed that their participation was voluntary and their responses confidential. Written informed consent was obtained.

\section{RESULTS}

A total of 406 women completed the questionnaire during their postpartum hospital stays. Characteristics of the study population are shown in table 1 . There was a significant difference in the variable 'ethnicity/nationality' between the two groups. Fifty-one $(25.3 \%)$ were women from 'other European countries' in the group of the humanised model, and there were only $8(3.9 \%)$ in the other group. The univariate associations between sociodemographic data and overall satisfaction showed that parity was the only variable associated with overall satisfaction, multiparas being more satisfied than primiparas. No significant association was found between overall satisfaction and maternal age, ethnicity, marital status, education, labour situation or attendance to prenatal classes.

\begin{tabular}{|c|c|c|c|}
\hline Models of birth & $\begin{array}{l}\text { Biomedical } \\
204 \\
\text { N (\%) } \\
\end{array}$ & $\begin{array}{l}\text { Humanised } \\
202 \\
\text { N (\%) } \\
\end{array}$ & p Value \\
\hline Age (year) & & & 0.214 \\
\hline$\leq 18$ & $6(3)$ & $2(1)$ & \\
\hline 19-35 & $145(71.8)$ & $150(74.2)$ & \\
\hline$\geq 35$ & $51(25.2)$ & $50(25.8)$ & \\
\hline Ethnicity/nationality & & & 0.0005 \\
\hline Spain & $171(83.8)$ & $123(60.9)$ & \\
\hline $\begin{array}{l}\text { Other European } \\
\text { countries }\end{array}$ & $8(3.9)$ & $51(25.3)$ & \\
\hline South American & $20(9.8)$ & $18(8.9)$ & \\
\hline African & $4(2)$ & $9(4.5)$ & \\
\hline Marital status & & & 0.351 \\
\hline $\begin{array}{l}\text { Married/ } \\
\text { cohabiting }\end{array}$ & $196(96.1)$ & $191(94.6)$ & \\
\hline Single & $8(3.9)$ & $7(3.5)$ & \\
\hline Others & $0(0)$ & $2(1)$ & \\
\hline Education & & & 0.078 \\
\hline $\begin{array}{l}\text { Elementary } \\
\text { school }\end{array}$ & 69 (33.3) & $76(37.6)$ & \\
\hline High school & $56(27.4)$ & $73(36.1)$ & \\
\hline University & 77 (37.7) & $51(25.2)$ & \\
\hline Employment status & & & 0.590 \\
\hline Employed & 109 (53.4) & $101(50)$ & \\
\hline Unemployed & $92(45.1)$ & $95(47)$ & \\
\hline Parity & & & 0.165 \\
\hline Primiparous & $110(53.9)$ & $95(47)$ & \\
\hline Multiparous & $94(46.1)$ & 107 (53) & \\
\hline Prenatal classes & & & 0.437 \\
\hline Yes & $105(51.5)$ & $95(47)$ & \\
\hline No & $98(48)$ & $104(51.5)$ & \\
\hline Twin pregnancy & & & 0.713 \\
\hline Yes & $4(2)$ & $3(1.5)$ & \\
\hline No & $200(98)$ & $199(98.5)$ & \\
\hline \multicolumn{4}{|c|}{$\begin{array}{l}\text { In table } 1 \text {, some participants have missing data. In the biomedical } \\
\text { model: one in the ethnicity variable, three in the education } \\
\text { variable, three in the 'labour situation' variable and one in the } \\
\text { 'prenatal classes' variable. In the humanised model: one in } \\
\text { the ethnicity variable, two in the 'marital status' variable, two in the } \\
\text { education variable, six in the 'labour situation variable' and three } \\
\text { in the 'prenatal classes' variable. These data were provided in } \\
\text { the sociodemographic questionnaire completed by the women } \\
\text { who participated in the study. }\end{array}$} \\
\hline
\end{tabular}


Table 2 Birth data ( $n=406$; significant results in bold)

\begin{tabular}{|c|c|c|c|}
\hline Models of birth & $\begin{array}{l}\text { Biomedical } \\
204 \\
\text { N (\%) }\end{array}$ & $\begin{array}{l}\text { Humanised } \\
202 \\
\text { N (\%) }\end{array}$ & p Value \\
\hline Beginning of labour & & & 0.0005 \\
\hline Spontaneous & $66(32.4)$ & $137(67.8)$ & \\
\hline Stimulation & 70 (34.3) & $1(0.5)$ & \\
\hline Induction & 68 (33.3) & $64(31.7)$ & \\
\hline Pain relief & & & 0.0005 \\
\hline No pain relief & $9(4.4)$ & $40(19.8)$ & \\
\hline Epidural & $172(84.3)$ & $132(65.3)$ & \\
\hline Alternative pain relief & $2(1)$ & $17(8.4)$ & \\
\hline Local anaesthesia & $13(6.4)$ & $11(5.4)$ & \\
\hline Rachianaesthesia & $3(1.5)$ & $2(1)$ & \\
\hline Mode of delivery & & & 0.004 \\
\hline Normal vaginal & $140(68.6)$ & $165(81.7)$ & \\
\hline Instrumental vaginal & 48 (23.5) & $23(11.4)$ & \\
\hline Emergency caesarean & $16(7.8)$ & $14(6.9)$ & \\
\hline Length of labour (hours) & & & 0.011 \\
\hline $0-4$ & $69(34.2)$ & $93(46)$ & \\
\hline$>4$ & $133(65.8)$ & $108(54)$ & \\
\hline Postpartum length of stay (days) & & & 0.589 \\
\hline 2 & $188(92.1)$ & $188(93.1)$ & \\
\hline 3 & $16(7.8)$ & $14(6.9)$ & \\
\hline Condition of the perineum & & & 0.0005 \\
\hline Intact perineum & $42(20.6)$ & $81(40.1)$ & \\
\hline First-degree tear & $40(19.6)$ & $62(30.7)$ & \\
\hline Second-degree tear & $12(5.9)$ & $34(16.8)$ & \\
\hline Third-degree tear & $0(0)$ & $1(0.5)$ & \\
\hline Episiotomy & $100(49)$ & $24(11.9)$ & \\
\hline Apgar $1 / 5 \mathrm{~min}$ & & & $0.290 / 0.243$ \\
\hline Apgar $\geq 9$ at $1 \mathrm{~min}$ & $192(94.1)$ & $189(93.6)$ & \\
\hline Apgar $\geq 9$ at $5 \mathrm{~min}$ & $201(98.6)$ & $201(99.5)$ & \\
\hline Type of birth according to gestational age & & & 0.599 \\
\hline Preterm birth & $8(3.9)$ & $6(3)$ & \\
\hline Term birth & $196(96.1)$ & $196(97)$ & \\
\hline
\end{tabular}

Table 2 lists the birth data. There were differences in the following variables: beginning of labour, pain relief, mode of delivery, length of labour and condition of the perineum (table 2). There were better obstetrical outcomes in the humanised model than in the biomedical one. A more spontaneous beginning of labour, normal vaginal deliveries, less length of labour and fewer episiotomies occurred in the humanised model than in the biomedical one (table 2).

Hospital A registered six preterm births, while hospital B had six. This information was not included in the tables because the difference was negligible between the two groups analysed, and this factor did not affect the women's satisfaction.

From the total questionnaire score (100), resulted at the humanised model of care a mean $(\mathrm{M})=82.01$ and $\mathrm{SD}=7.97$ and at the biomedical model of care and an $\mathrm{M}=78.33$ and $\mathrm{SD}=8.46(\mathrm{p}=0.0005)$.
Tables 3 and 4 show the comparative of the questionnaire results per item. In the analysis of the results per item, statistical differences were found in eight of the nine subscales: 'professional support, expectations, holding the baby, support from the husband, pain in labour, pain after delivery, environment, general satisfaction' (tables 3 and 4). Although most of the women in hospital B indicated satisfaction in most subscales, the highest scores were recorded in the humanised model of maternity care (tables 3 and 4). No differences were found between the two models in the subscale 'control', but a statistically significant relationship appeared between general satisfaction and control in labour. A higher level of general satisfaction was related to a higher level of control in labour $(p=0.0005)$. The DA indicated that the items which contributed most to the discrimination of the two models of maternity care were: 'All my caregivers treated me in the most friendly and 
Table 3

\begin{tabular}{|c|c|c|c|c|c|c|c|c|c|}
\hline \multirow[b]{2}{*}{ Models of birth } & \multicolumn{4}{|c|}{ Biomedical model } & \multicolumn{4}{|c|}{ Humanised model } & \multirow[b]{2}{*}{ p Value } \\
\hline & $\begin{array}{l}\text { TA } \\
\text { N (\%) }\end{array}$ & $\begin{array}{l}\text { A } \\
\text { N (\%) }\end{array}$ & $\begin{array}{l}\text { D } \\
\text { N (\%) }\end{array}$ & $\begin{array}{l}\text { TD } \\
\mathrm{N}(\%)\end{array}$ & $\begin{array}{l}\text { TA } \\
\text { N (\%) }\end{array}$ & $\begin{array}{l}\text { A } \\
\text { N (\%) }\end{array}$ & $\begin{array}{l}\text { D } \\
\text { N (\%) }\end{array}$ & $\begin{array}{l}\text { TD } \\
\text { N (\%) }\end{array}$ & \\
\hline \multicolumn{10}{|l|}{ Professional support } \\
\hline All my labour carers were very supportive. & $147(72.1)$ & $53(26)$ & $4(2)$ & $0(0)$ & $173(85.6)$ & $29(14.4)$ & $0(0)$ & $0(0)$ & 0.001 \\
\hline $\begin{array}{l}\text { Carers always listened very, very carefully } \\
\text { to everything that I had to say. }\end{array}$ & $143(70.1)$ & $56(27.5)$ & $4(2)$ & $1(0.5)$ & $173(85.6)$ & $29(14.4)$ & $0(0)$ & $0(0)$ & 0.001 \\
\hline $\begin{array}{l}\text { During labour, there was always a carer to } \\
\text { explain things so that I could understand. }\end{array}$ & $146(71.6)$ & $46(22.5)$ & $9(4.4)$ & $3(1.5)$ & $158(78.2)$ & 39 (19.3) & $4(2)$ & $1(0.5)$ & 0.265 \\
\hline $\begin{array}{l}\text { All my carers treated me in the most } \\
\text { friendly and courteous manner possible.* }\end{array}$ & $150(73.5)$ & $43(21.1)$ & $9(4.4)$ & $2(1)$ & $181(89.6)$ & $21(10.4)$ & $0(0)$ & $0(0)$ & 0.0005 \\
\hline My carers couldn't have been more helpful. & $153(75)$ & $50(24.5)$ & $1(0.5)$ & $0(0)$ & $175(86.6)$ & $27(13.4)$ & $0(0)$ & $0(0)$ & 0.009 \\
\hline \multicolumn{10}{|l|}{ Expectations } \\
\hline My labour went totally normally, ${ }^{*}$ & $103(51)$ & $76(37.6)$ & $16(7.9)$ & $7(3.5)$ & $117(58.2)$ & $59(29.4)$ & $19(9.5)$ & $6(3)$ & 0.339 \\
\hline $\begin{array}{l}\text { The labour went nearly exactly as I had } \\
\text { hoped that it would. }\end{array}$ & $68(33.7)$ & 77 (38.1) & $34(16.8)$ & $23(11.4)$ & 97 (48.3) & $55(27.4)$ & $27(13.4)$ & $22(10.9)$ & 0.022 \\
\hline $\begin{array}{l}\text { The delivery went almost completely as I } \\
\text { had hoped that it would. }\end{array}$ & $63(31)$ & $71(35)$ & $47(23.2)$ & $22(10.8)$ & $94(46.8)$ & $55(27.4)$ & $40(19.9)$ & $12(6)$ & 0.009 \\
\hline My labour was just about the right length. & $90(44.6)$ & $79(39.1)$ & $17(21.1)$ & $16(7.9)$ & $105(52.2)$ & $56(27.9)$ & $25(20.9)$ & $15(7.5)$ & 0.085 \\
\hline \multicolumn{10}{|l|}{ Holding baby } \\
\hline $\begin{array}{l}\text { I got to see my baby at exactly the right } \\
\text { time after she/he was born. }\end{array}$ & $189(92.6)$ & $14(6.9)$ & $1(0.5)$ & $0(0)$ & $192(95.5)$ & $6(3)$ & $1(0.5)$ & $2(1)$ & 0.158 \\
\hline $\begin{array}{l}\text { After my baby was born, I was not given } \\
\text { him/her quite as soon as I wanted. }\end{array}$ & $17(8.4)$ & $19(9.4)$ & $51(25.1)$ & $116(57.1)$ & $15(7.5)$ & $31(15.4)$ & $7(3.5)$ & $148(73.6)$ & 0.002 \\
\hline $\begin{array}{l}\text { I needed to hold my baby a little earlier } \\
\text { than I did. }\end{array}$ & $14(6.9)$ & 24 (11.9) & $52(25.7)$ & $112(55.4)$ & $14(7)$ & $9(4.5)$ & $37(18.4)$ & $141(70.1)$ & 0.005 \\
\hline \multicolumn{10}{|l|}{ Support from husband } \\
\hline $\begin{array}{l}\text { My birth partner/husband helped me to } \\
\text { understand what was going on when I was } \\
\text { in labour. }\end{array}$ & $115(58.7)$ & $62(31.6)$ & $16(8.2)$ & $3(1.5)$ & $146(72.6)$ & $38(18.9)$ & $11(5.5)$ & $6(3)$ & 0.010 \\
\hline $\begin{array}{l}\text { My birth partner/husband couldn't have } \\
\text { supported me any better. }\end{array}$ & $163(81.9)$ & $30(15.1)$ & $4(2)$ & $2(1)$ & $182(90.5)$ & $18(9)$ & $0(0)$ & $1(0.5)$ & 0.039 \\
\hline $\begin{array}{l}\text { I could have had a bit more help from my } \\
\text { birth partner/husband. }\end{array}$ & $116(59.5)$ & 46 (23.6) & $11(5.6)$ & $22(11.3)$ & $137(67.8)$ & $34(16.8)$ & $12(5.9)$ & $19(9.4)$ & 0.298 \\
\hline
\end{tabular}


Table 4 Comparative of the questionnaire results per items of the subscales 'pain in labour', 'pain after delivery', 'environment', 'control' and 'general satisfaction'

(significant results in bold)

\begin{tabular}{|c|c|c|c|c|c|c|c|c|c|}
\hline \multirow[b]{2}{*}{ Models of birth } & \multicolumn{4}{|c|}{ Biomedical model } & \multicolumn{4}{|c|}{ Humanised model } & \multirow[b]{2}{*}{ p Value } \\
\hline & $\begin{array}{l}\text { TA } \\
\mathrm{N}(\%)\end{array}$ & $\begin{array}{l}\text { A } \\
N(\%)\end{array}$ & $\begin{array}{l}\mathrm{D} \\
\mathrm{N}(\%)\end{array}$ & $\begin{array}{l}\text { TD } \\
\text { N (\%) }\end{array}$ & $\begin{array}{l}\text { TA } \\
\text { N (\%) }\end{array}$ & $\begin{array}{l}\text { A } \\
N(\%)\end{array}$ & $\begin{array}{l}\text { D } \\
\text { N (\%) }\end{array}$ & $\begin{array}{l}\text { TD } \\
\mathrm{N}(\%)\end{array}$ & \\
\hline \multicolumn{10}{|l|}{ Pain in labour } \\
\hline $\begin{array}{l}\text { I should have been offered something more to } \\
\text { relieve my labour pains. }\end{array}$ & $31(15.4)$ & $29(14.4)$ & 85 (42.3) & 56 (27.9) & $21(10.4)$ & 26 (12.9) & 69 (34.2) & $86(42.6)$ & 0.018 \\
\hline I got excellent pain relief in labour. & $107(52.7)$ & $65(32)$ & $12(5.9)$ & $19(9.4)$ & $115(56.9)$ & $59(29.2)$ & $16(7.9)$ & $12(5.9)$ & 0.435 \\
\hline $\begin{array}{l}\text { More pain relief would have made my labour } \\
\text { easier. }\end{array}$ & $22(11)$ & $37(18.5)$ & 75 (37.5) & 66 (33) & 26 (12.9) & $23(11.4)$ & $61(30.2)$ & $92(45.5)$ & 0.025 \\
\hline \multicolumn{10}{|l|}{ Pain after delivery } \\
\hline $\begin{array}{l}\text { I should have been offered something more to } \\
\text { relieve the pains I had after my baby was born.* }\end{array}$ & $15(7.4)$ & $23(11.3)$ & $104(51.2)$ & $61(30)$ & $9(4.5)$ & $20(9.9)$ & $76(37.6)$ & $97(48)$ & 0.003 \\
\hline $\begin{array}{l}\text { I was in a fair bit of pain immediately after the } \\
\text { birth. }^{*}\end{array}$ & $29(14.2)$ & $62(30.4)$ & $62(30.4)$ & $51(25)$ & $41(20.3)$ & 73 (36.1) & $44(21.8)$ & $44(21.8)$ & 0.089 \\
\hline I didn't need a lot of pain relief after the birth. & $63(31)$ & 79 (38.9) & $43(21.2)$ & $18(8.9)$ & $91(45.3)$ & $76(37.8)$ & $26(12.9)$ & $8(4)$ & 0.004 \\
\hline \multicolumn{10}{|l|}{ Environment } \\
\hline My birth room was a little impersonal and clinical. & $24(11.8)$ & 47 (23.2) & $89(43.8)$ & $43(21.2)$ & $15(7.5)$ & $19(9.5)$ & $80(39.8)$ & $87(43.3)$ & 0.0005 \\
\hline $\begin{array}{l}\text { The area where I gave birth was very pleasant } \\
\text { and relaxing.* }\end{array}$ & $54(26.5)$ & $82(40.2)$ & $58(28.4)$ & $10(4.9)$ & $97(48)$ & 77 (38.1) & $23(11.4)$ & $5(2.5)$ & 0.0005 \\
\hline \multicolumn{10}{|l|}{ Control } \\
\hline Everyone seemed to tell me what to do in labour. & $135(66.5)$ & $56(27.6)$ & $9(4.4)$ & $3(1.5)$ & $142(70.3)$ & $54(26.7)$ & $4(2)$ & $2(1)$ & 0.506 \\
\hline $\begin{array}{l}\text { Labour was just a matter of doing what I was told } \\
\text { by my carers. }\end{array}$ & $103(51.5)$ & 67 (33.5) & $22(11)$ & $8(4)$ & $101(50.8)$ & 67 (33.7) & $22(11.1)$ & $9(4.5)$ & 0.995 \\
\hline \multicolumn{10}{|l|}{ General satisfaction } \\
\hline $\begin{array}{l}\text { The way my labour care was provided could not } \\
\text { have been improved. }\end{array}$ & $112(54.9)$ & $64(31.4)$ & $16(7.8)$ & $12(5.9)$ & $123(60.9)$ & $66(32.7)$ & $10(5)$ & $3(1.5)$ & 0.062 \\
\hline $\begin{array}{l}\text { I am satisfied with just one or two things about } \\
\text { the labour care that I received.* }\end{array}$ & $28(13.8)$ & $21(10.3)$ & $86(42.4)$ & 68 (33.5) & $15(7.4)$ & $11(5.4)$ & $67(33.2)$ & $109(54)$ & 0.0005 \\
\hline
\end{tabular}


ourteous manner possible', 'My labour went totally normally', 'I should have been offered something more to relieve the pains I had after my baby was born', 'I was in a fair bit of pain immediately after the birth', 'The area where I gave birth was very pleasant and relaxing' and 'I am satisfied with just one or two things about the labour care that I received' (tables 3 and 4).

\section{DISCUSSION}

As in previous research, which identified parity as a variable affecting childbirth satisfaction, ${ }^{4}{ }^{25-27}$ multiparous women in this study had higher total childbirth satisfaction than did primiparous women. In other studies, no difference has been reported in satisfaction between multiparous and primiparous women. ${ }^{28-32}$

Although differences were found in ethnicity between the two groups compared in this study, no significant associations appeared between overall satisfaction and ethnicity, in agreement with other authors. ${ }^{43}$ In contrast, other research in England showed that ethnic minority women had a poorer experience of maternity services than did white British women. ${ }^{34-36}$

This study showed that the influence of the model of maternity care concerns the obstetric results as well as the level of mother's satisfaction. Higher mother's satisfaction was found in the humanised model of care compared with the biomedical one. Other authors have also evidenced that high levels of intervention in normal birth can lead to the dissatisfaction of women and their families. $^{37-42}$

Support from the caregivers during labour was a strong predictor of childbirth satisfaction. ${ }^{4}$ The most important aspects of professional support were: communication, information, allowing the mother to become involved in decision-making and to express her feelings during labour. ${ }^{6}{ }^{43-48}$ The subscale 'professional support' scored higher in the humanised model than in the biomedical one in this study. Midwives were the professionals who attended women during normal labour and birth at the hospital where the humanised model was followed. Other studies have also reported that childbirth satisfaction was closely related to midwife support. ${ }^{4} 72532394249-51$ Analysing professionals who can be considered better to support women and their families during labour and birth, the WHO concluded that the midwife appears to be the most appropriate and cost-effective type of healthcare provider to be assigned to the care of normal pregnancy and normal birth, including risk assessment and the recognition of complications. ${ }^{10}$ In a qualitative study, women said that the midwife should be competent in addressing psychological and emotional support, should be a good listener, should involve parents in decisions concerning their care, and should make the mother feel safe, confident and respected. ${ }^{52}$ In several studies, where the midwife-led model and other models of care for childbearing women were compared, better obstetrical results were registered with the midwife-led model: more spontaneous births, fewer instrumental deliveries, fewer episiotomies and effects on the mother's choice of pain relief with no differences in neonatal results. ${ }^{53-56}$ In this study, better obstetrical results were found in the humanised model where the midwife's continuous presence and her autonomy were possible.

Several studies confirmed the relationship between expectations and childbirth satisfaction. ${ }^{4}$ Researchers have indicated that the degree of discrepancy between women's expectations for labour and birth and their experiences was important because, when women's expectations were met, they had higher childbirth satisfaction. $^{38}{ }^{57-60}$ Differences appeared in the subscale 'expectations' between the two groups studied. Higher scores were found in the group of the humanised model because women's expectations were met.

In the subscale 'holding the baby', the best results were found in the group of the humanised model. In this setting, after birth, the mother and baby had skin-to-skin contact for two hours and early breast feeding was encouraged. Several studies have shown the importance of early skin-to-skin contact because it decreased the mother's anxiety and depression levels at 48 hours after birth, improved early neonatal adaptation to breast feeding, and increased levels of childbirth satisfaction. ${ }^{61-64}$ Early mother-infant contact is considered one of the four most important factors for the mother's well-being after birth. Women gave special value to bonding with their infants and they were concerned about their safety and wanted to breast feed successfully. ${ }^{3365}$

In the items of the subscale 'support from the husband', the highest scores were found in the humanised model. The reason could be that the partner/ husband could stay with the woman in an individual home-like labour and birth room the entire time. In this setting, the mother's and her family's privacy could be respected. These results agree with previous studies where the benefits of continuous empathetic and physical support during labour have been described: shorter labour, the need for less medication and epidural analgesia, fewer operative deliveries, and better conditions of the baby after delivery. ${ }^{10}{ }^{12}$ This study shows that obstetrical results were better in the humanised model where support from the husband or partner was continuous.

Despite less use of epidural analgesia during labour in the hospital with a humanised model of maternity care, women had the perception of being provided adequate pain relief. On the other hand, in the biomedical model, with greater use of epidural analgesia, women expressed that it would have been better to receive more pain relief. Regarding the humanised model, women could choose between pharmacological and nonpharmacological pain relief. Therefore, women could see that their expectations about pain relief were met. If non-pharmacological pain relief was chosen, the midwife would give the support necessary to make the 
mother feel comfortable and helped. Other researchers have observed that women had higher satisfaction when they saw that their expectations about pain relief were met. ${ }^{102260}$ In the subscale 'pain after delivery', it was observed that women had less pain after delivery in the humanised model of maternity care than in the biomedical one, as well as less pain in the immediate postpartum period.

In this study, women did not like the common, clinical and impersonal labour, delivery and postpartum rooms. They preferred individual, pleasant and relaxing labour, delivery and postpartum rooms. Other studies have reported the same results. ${ }^{4} 1417325266-68$

Although there were no differences between the two models of maternity care in the subscale 'control', this study showed that higher levels of general satisfaction are related to a higher level of control. These findings were similar to the results of other researchers. ${ }^{30} 3238576568$

The main limitations of this study were the convenience sample and the moment chosen for completing the questionnaires. On the one hand, a convenience sample was chosen due to the relative cost and time required to obtain it. On the other hand, the postpartum stay is the moment when women may be experiencing the 'halo' effect, which is a result of the woman's relief at having a healthy baby. However, we are comparing two groups within the same time period. According to Hodnett's ${ }^{4}$ review, "There is insufficient evidence on which to base conclusions about the impact of timing of assessment of childbirth satisfaction. There may be no optimum time; it may be dependent on the purpose of the study".

In conclusion, the humanised model of maternity care, where the main professionals in normal birth are midwives, gave better obstetrical results and higher mother's childbirth satisfaction than did the biomedical model of care. Therefore, the humanised model should be promoted in strategies meant to reduce overmedicalised childbirths, to empower women, and to promote evidence-based maternity practices by obstetric health providers, administrators and policymakers.

Acknowledgements The authors are extremely grateful to the women who gave their time in completing the questionnaires and to Sheryl Richardson and Encarnación Hernández Sánchez for their unconditional help. The authors would like to thank the two hospitals, the University Hospital of Torrevieja and the University Hospital Virgen de la Arrixaca, for the opportunity they have granted to conduct this study.

Contributors MBCF and MEMR conceived and oversaw the study. MBCF, CBM and CCG undertook the literature review and collected the data. MCJ and MBCF participated in the design of the study, performed statistical analyses and reviewed the manuscript. All authors read and approved the final manuscript.

Funding This research received no specific grant from any funding agency in the public, commercial or not-for-profit sectors.

Competing interests None declared.

Patient consent Obtained.

Ethics approval Ethics Committee of Torrevieja and Virgen de la Arrixaca hospitals.
Provenance and peer review Not commissioned; externally peer reviewed.

Data sharing statement No additional data are available.

Open Access This is an Open Access article distributed in accordance with the Creative Commons Attribution Non Commercial (CC BY-NC 4.0) license, which permits others to distribute, remix, adapt, build upon this work noncommercially, and license their derivative works on different terms, provided the original work is properly cited and the use is non-commercial. See: http:// creativecommons.org/licenses/by-nc/4.0/

\section{REFERENCES}

1. Lomas J, Dore S, Enkin M, et al. The Labor and Delivery Satisfaction Index: the development and evaluation of a soft outcome measure. Birth 1987;14:125-9.

2. Simkin P. Just another day in a woman's life? Women's long term perceptions of their first birth experience. Part I. Birth 1991;18:203-10.

3. Simkin P. Just another day in a woman's life? Part II: nature and consistency of women's long-term memories of their first-birth experiences. Birth 1992;19:64-81.

4. Hodnett E. Pain and women's satisfaction with the experience of childbirth: a systematic review. Am J Obstet Gynecol 2002;186:160-72.

5. Séguin L, Therrien R, Champagne F, et al. The components of women's satisfaction with maternity care. Birth 1989;16:109-13.

6. Drew NC, Salmon P, Webb L. Mothers', midwives' and obstetricians views on the features of obstetric care which influence satisfaction with childbirth. BJOG 1989:96:1084-8.

7. Lavender T, Walkinshaw SA, Walton I. A prospective study of women's views of factors contributing to a positive birth experience. Midwifery 1999;15:40-6.

8. Davis-Floyd R. Culture and birth: the technocratic imperative. Birth Gaz 1994:11:25-5.

9. Wagner M. Fish can't see water: the need to humanize birth Int J Gynaecol Obstet 2001;75(Suppl 1):S25-37.

10. World Health Organization. Care in normal birth: a practical guide. Maternal and newborn health/safe motherhood unit. Geneva: WHO, 1996.

11. Enkin M, Keirse M, Renfrew M, et al. Effective care in pregnancy and childbirth. Oxford: Oxford University Press, 1995.

12. Enkin M, Keirse M, Neilson J, et al. A guide to effective care in pregnancy and childbirth. Oxford: Oxford University Press, 2000.

13. Brasil. Ministeiro de Salud de Brasil. Portaria GM/ $n^{\circ} .569$, del 1/6/ 2000. Programa de humanización en el prenatal y nacimiento. Brasil: 2000. Recuperado de http: //decs.bvs.br/cgi-bin/wxis1660. exe/decsserver/. Consultado: 16/03/2012.

14. Behruzi R, Hatem M, Fraser W, et al. Facilitators and barriers in the humanization of childbirth practice in Japan. BMC Pregnancy Childbirth 2010;10:25

15. Da Silva LM, Barbieri M, Fustinoni SM. [Living the birth process in a humanized assistance model]. $R$ Bras Enferm REBEn 2011;64:60-5.

16. Gonçalves R, de Azevedo Aguiar C, Merighi MA, et al. [Experiencing care in the birthing center context: the users perspective]. Rev Esc Enferm USP 2011;45:62-70.

17. Behruzi R, Hatem M, Goulet $L$, et al. The facilitating factors and barriers encountered in the adoption of a humanized birth care approach in a highly specialized university affiliated hospital. BMC Women's Health 2011;11:53.

18. Wagner M. El cuidado maternal en España 2006: La necesidad de humanizar el parto. Med Naturist 2006;10:598-610.

19. Junta de Andalucía. Embarazo, parto y puerperio: proceso asistencial integrado. 2nd edn. Sevilla: Conserjería de Salud, 2005.

20. Generalitat de Catalunya. Protocol per l'assistècia natural al part normal. Barcelona: Departament de Salut, 2007.

21. Gobierno de Cantabria. Decreto 23/2007, de 1 de marzo, sobre los derechos de la madre, el padre y el recién nacido en relación con el nacimiento en el ámbito sanitario. BOC, 2007; no. 54

22. FAME. Iniciativa Parto Normal. Documento de Consenso. Barcelona: Federación de Asociaciones de Matronas de España, 2007.

23. Ministerio de Sanidad y Consumo. Estrategia de Atención al Parto Normal en el Sistema Nacional de Salud. (Consultado 2/01/2012). Recuperado de: Catálogo general publicaciones oficiales, 2008. http://www.060.es

24. Smith LFP. Development of a multidimensional labour satisfaction questionnaire: dimensions, validity, and internal reliability. Qual Health Care 2001;10:17-22. 
25. Waldenström U. Experience of labor and birth in 1111 women. $J$ Psychosom Res 1999;5:471-82.

26. Waldenström U. Women's memory of childbirth at two months and one year after birth. Birth 2003;30:248-54.

27. Rijnders $\mathrm{M}$, Baston $\mathrm{H}$, Schönbeck $\mathrm{Y}$, et al. Perinatal factors related to negative or positive recall of birth experience in women 3 years postpartum in the Netherlands. Birth 2008;35:107-16.

28. Ranta P, Spalding M, Kangas-Saarela T, et al. Maternal expectations and experiences of labour pain: opinions of 1091 Finnish parturients. Acta Anaesthesiol Scand 1995;39:60-6.

29. Pelkonen M, Perälä MJ, Vehviläinen-Julkunen K. Participation of expectant mothers in decision making in maternity care: results of a population-based survey. J Adv Nurs 1998;28:21-9.

30. Waldenström U, Borg IM, Ollson B, et al. The childbirth experience: a study of 295 new mothers. Birth 1996;23:144-53.

31. Van Teijlingen E, Hundley V, Rennie AM, et al. Maternity satisfaction studies and their limitations, what is must still be best. Birth 2003;30:75-82.

32. Waldenström U, Rudman A, Hildingsson I. Intrapartum and postpartum care in Sweden: women's opinions and risk factors for not being satisfied. Acta Obstet Gynecol Scand 2006;85:551-60.

33. Sadler L, Davison T, McCowan L. Maternal satisfaction with active management of labor: a randomized controlled trial. Birth 2001:28:225-35.

34. Henderson J, Gao H, Redshaw M. Experiencing maternity care: the care received and perceptions of women from different ethnic groups. BMC Pregnancy Childbirth 2013;13:196.

35. Raleigh VS, Hussey D, Seccombe I, et al. Ethnic and social inequalities in women's experience of maternity care in England: results of a national survey. $J R$ Soc Med 2010;103:188-98.

36. Jomeen J, Redshaw M. Ethnic minority women's experience of maternity services in England. Ethn Health 2013;18:280-96.

37. Green J, Coupland V, Kitzinger J. Expectations, experiences, and psychological outcomes of childbirth: a prospective study of 825 women. Birth 1990;17:15-24.

38. Goodman P, Mackey MC, Tavakoli AS. Factors related to childbirth satisfaction. J Adv Nurs 2004:46:212-19.

39. Waldenström $\mathrm{U}$. Why do some women change their opinion about childbirth over time? Birth 2004;31:102-7.

40. Nystedt A, Hogberg $U$, Lundman B. The negative birth experience of prolonged labour: a case-referent study. $J$ Clin Nurs 2005;14:579-86.

41. Wiklund I, Edman G, Ryding EL, et al. Expectation and experiences of childbirth in primiparae with caesarean section. BJOG 2008;115:324-31.

42. Gungor I, Beji NK. Development and psychometric testing of the scales for measuring maternal satisfaction in normal and caesarean birth. Midwifery 2012;28:348-57.

43. Ware JE, Snyder MK. Dimensions of patient attitudes regarding doctors and medical care services. Med Care 1975;13:669-82.

44. Kirke PN. Mothers' views of obstetric care. BJOG 1980;87:1029-33.

45. Kirke PN. Mothers' views of care in labour. BJOG 1980;87:1034-8.

46. Hung CH, Hsu YY, Lee SF. Couples' satisfaction with health care service during labor and delivery. Kaohsiung J Med Sci 1997;13:255-62.

47. Santos OMB, Siebert ERC. The humanization of birth experience at the University of Santa Catarina maternity hospital. Int J Gynaecol Obstet 2001;75(Suppl 1):S73-9.

48. Soares RM, Moreira E, Carmo M. [Aspects of women's satisfaction with childbirth care in a maternity hospital in Rio de Janeiro]. Cad Saude Pública 2004;20(Suppl 1):552-62.

49. Knapp L. Childbirth satisfaction: the effects of internality and perceived control. J Perinat Educ 1996;5:7-16.
50. Peterson WE, Charles C, DiCenso A, et al. The Newcastle Satisfaction with Nursing Scale: a valid measure of maternal satisfaction with inpatient postpartum nursing care. $J$ Adv Nurs 2005;52:672-81.

51. Abushaikha L, Sheil EP. Labour stress and nursing support: how do they relate? J Int Womens Stud 2006;7:198-208.

52. Hildingsson I, Thomas JE. Women's perspectives on maternity services in Sweden: processes, problems and solutions. J Midwifery Womens Health 2007;52:126-33.

53. Hatem M, Sandall J, Devane D, et al. Midwife-led versus other models of care for childbearing women. Cochrane Database Syst Rev 2008;(4):CD004667.

54. Ministerio de Sanidad y Política Social. Grupo de Trabajo de la Guía de Práctica Clínica sobre la Atención al Parto Normal. Guía de Práctica Clínica sobre la Atención al Parto Normal. Madrid. Plan nacional para el Sistema Nacional de Salud del Ministerio de Sanidad y Política Social. Agencia de Evaluación de Tecnologías Sanitarias del País Vasco. Guías de Práctica Clínica en el SNS, 2010; OSTEBA N 2009/01.

55. Hodnett ED, Gates S, Hofmeyr GJ, et al. Continuous support for women during childbirth. Cochrane Database Syst Rev 2011;2: CD003766.

56. Aune I, Amundsen HH, Skaget LC. Is a midwife's continuous presence during childbirth a matter of course? Midwives' experiences and thoughts about factors that may influence their continuous support of women during labour. Midwifery 2014;30:89-95

57. Christiaens W, Bracke P. Assessment of social psychological determinants of satisfaction with child birth in a cross-national perspective. BMC Pregnancy Childbirth 2007;7:26.

58. Hauck Y, Fenwick J, Downie J, et al. The influence of childbirth expectations on Western Australian women's perceptions of their birth experience. Midwifery 2007;23:235-47.

59. Lally JE, Murtagh MJ, Macphail S, et al. More in hope than expectation: a systematic review of women's expectations and experience of pain relief in labour. BMC Med 2008;14:6-7.

60. Mas-Pons R, Barona-Vilar C, Carreguí-Vilar S, et al. Satisfacción de las mujeres con la experiencia del parto: validación de la Mackey Satisfaction Childbirth Rating Scale. Gac Sanit 2012;26:236-42.

61. Tessier R, Cristo M, Velez S, et al. Kangaroo mother care and the bonding hypothesis. Pediatrics 1998;102:390-1.

62. Gray L, Watt L, Blass E. Skin-to-skin contact is analgesic in healthy newborns. Pediatrics 2000;105:14-19.

63. Feldman R, Eildeman A, Sirota L, et al. Comparison of skin-to-skin (kangaroo) and traditional care parenting outcomes and preterm infant development. Pedriatics 2002;110:16-26.

64. Rivara Dávila G, Rivara Dávila P, Cabrejos K, et al. Analgesia y otros beneficios del contacto piel a piel inmediato en recién nacidos sanos a término. Rev Peruana Pediatría 2007;59:18-25.

65. Gamble J, Creedy DK, Teakle B. Women's expectations of maternity services: a community-based survey. Women Birth 2007;20:115-20.

66. D'Ambruoso L, Abbey M, Hussein J. Please understand when I cry out in pain: women's accounts of maternity services during labour and delivery in Ghana. BMC Public Health 2005;22:140.

67. Hodnett ED, Downe S, Edwards N, et al. Home-like versus conventional institutional settings for birth. Cochrane Database Syst Rev 2005;(1):CD000012.

68. Rudman A, El-Khouri B, Waldenström U. Evaluating multi-dimensional aspects of postnatal hospital care. Midwifery 2008;24:425-41. 